\title{
REMEDIES: A NEGLECTED CONTRIBUTION
}

\section{Andrew Tettenborn*}

Professor Burrows, in the introduction to his excellent book on Remedies for Torts and Breaches of Contract, lamented the tendency of most English law students to binge on substantive law at the expense of remedies. He was, of course, entirely right. His point was also particularly apt in the context of the teaching of the common law. For there, more almost than in any other system, practitioners recognise that in practice the old maxim nearly always falls to be reversed: in England at least, it is normally a case of ubi remedium, ibi ius and not the other way round. Remedies are the vital element in shaping, moderating and at times extending the substantive rules under which we live: and we must always remember that legal advice is, at bottom, simply advice as to the remedy likely to be available (or unavailable) to the client.

A corollary of this is a further curiosity of the English law of remedies: namely, that the remedies available to a plaintiff are regarded, to an extent which will astonish a non-common lawyer, as matters of law, subject to their own detailed rules, sub-rules and exceptions. A French lawyer, for example, may be happy to regard the subject of remoteness of damage as a factual issue, as part of procedure, subject in practice to the pouvoir souverain of the juge du fond or trier of fact. ${ }^{1}$ In England, by contrast, the topic is one which is regularly litigated, where the litigation is routinely reported, where decisions are regularly interfered with on appeal, and on which as a result there is a great deal of authority in all tribunals up to and including the House of Lords.

The relative importance of remedies as a matter of law in England is one excellent reason to concentrate specifically on Lord Denning's contribution to this subject in the context of the law of obligations. There is also another, possibly more cynical, consideration: arguably, his ideas on remedies have turned out to have more long-lasting effects than his attempts to reform substantive law. In the latter case the seeds he has

\footnotetext{
* Bracton Professor of Law, the University of Exeter.

${ }^{1}$ Mazeaud \& Chabas, Responsabilité Civile, (6th ed., Montchrestien, 1976) vol. 3.1, at pp.708 et seq., sum up the position nicely.
} 
sown, however wholesome and potentially fertile, have often fallen on stony judicial ground (how often is a law student told "there was once a contrary suggestion by Lord Denning, but this is now clearly discountenanced"?). By contrast, a remarkable number of the remedial innovations with which he allied himself in the Court of Appeal have now become accepted parts of the legal landscape applied almost without thinking by practitioners every day.

The law of remedies covers, on principle, a multitude of sins. This essay will, however, concentrate on its two most important components, on which there is most material to work: that is, money awards (particularly damages) and injunctions. As between these, it is probably true to say that most of Lord Denning's higher profile decisions have concerned the former. On the other hand, considerably more thoughtprovoking have been certain views expressed by him on specific relief, notably injunctions. It is, therefore, to these that we will turn first.

\section{SPECIFIC REMEDIES AND INJUNCTIONS (1): INTERLOCUTORY ORDERS}

There is no doubt over which are the two outstanding contributions made in this area by the Court of Appeal under Lord Denning M.R.'s tutelage. They must be the Mareva jurisdiction and the Anton Piller order. The former, indeed, he can be said to have initiated, since in no previous case prior to the leading decision in N.Y.K. v. Karageorgis had an application for such an order been successful. ${ }^{2}$ The latter he strictly did not, since the practice of issuing such orders had already grown up in the High Court even before the seminal Anton Piller K.G. v. Manufacturing Processes: but even here there is no doubt whatever that it was that court that gave it the final stamp of approval. ${ }^{3}$ And, in both cases, what is equally worthy of notice is that that same court - or rather, that court presided over by the same judge - kept a careful watch on what it had fostered and helped it to develop. ${ }^{4}$

The subsequent development of the Mareva jurisdiction is the most obvious example of this, with a truly astonishing number of subsequent judgments by Lord Denning M.R. devoted to its development and

\footnotetext{
${ }^{2}$ [1975] 3 All E.R. 282.

3 [1976] Ch. 55.

${ }^{4}$ See, for example, Lord Denning's valiant attempt in Rank Film Distributors v. Video Information Centre [1980] 2 All E.R. 273 to prevent emasculation of the Anton Piller order by the privilege against self-incrimination. Although it was reversed in the House of Lords ([1981] 2 All E.R. 76), it is not surprising that the latter decision was in turn reversed by statute, thus restoring the law to what Lord Denning M.R. would have liked it to be in the first place (Supreme Court Act 1981, s.72).
} 


\section{REMEDIES: A NEGLECTED CONTRIBUTION}

exegesis. After the blessing in principle of such injunctions in the Karageorgis case and later in the more considered Mareva Compañia Naviera v. International Bulk Carriers ${ }^{5}$ (which incidentally managed to dispose to everyone's satisfaction of clear contrary authority in courts up to and including the Court of Appeal ${ }^{6}$ ), we have a congeries of further decisions, in all of which Lord Denning M.R. participated, going on to elucidate the type of prima facie case the plaintiff must prove in order to get relief, ${ }^{7}$ the protections and indulgences to be allowed to the defendant, ${ }^{8}$ and the position of banks and other intermediaries finding themselves embrangled in the litigation, ${ }^{9}$ together with what is in all but name a Practice Direction on the procedure to be followed. ${ }^{10}$ There are also other important matters dealt with - in particular, confirmation that such orders are not limited to commercial cases, ${ }^{11}$ to foreign defendants of doubtful pedigree, ${ }^{12}$ or to threats to remove assets from the jurisdiction (the prospect of their being frittered away within it being quite enough): ${ }^{13}$ and, as if that was not enough, an attempt to extend the jurisdiction to cover claims brought abroad ${ }^{14}$ - the latter unsuccessful, though later effectuated in part by statutory change (as regards European claims). ${ }^{15}$

The Mareva and Anton Piller jurisdiction hit the headlines, and with reason. But they were by no means the only examples of Lord Denning's influence in the interlocutory area. Less well-known, but in a way just as important, was his position on interim injunctions generally. In 1975, it will be remembered, the House of Lords in American Cyanamid v. Ethicon Ltd. had recast the guidelines for their availability. ${ }^{16}$ Essentially this recasting had involved downplaying the old issue of whether the claimant had shown a prima facie case that he was right, and instituting

\footnotetext{
5 [1975] 2 Lloyd's Rep. 509.

${ }^{6}$ Notably Lister v. Stubbs (1890) 45 Ch.D. 1 at 14 and Scott v. Scott [1951] P. 193 at 196. They are conveniently listed in Lord Denning M.R.'s judgment in the Pertamina case referred to below: see [1977] 3 All E.R. 324 at pp.332-333.

${ }^{7}$ Rasu Maritima v. Pertamina \& Another [1977] 3 All E.R. 324.

${ }^{8}$ E.g., Z v. A [1982] 1 All E.R. 556.

${ }^{9}$ See Intraco v. Notis [1981] 2 Lloyd's Rep. 256; Power Curber International v. National Bank of Kuwait [1981] 3 All E.R. 607; and Z v. A, ibid.

${ }^{10} Z$ v. A, ibid.

${ }^{11}$ Allen v. Jambo Holdings [1980] 2 All E.R. 502.

${ }^{12}$ See a series of cases exemplified by Third Chandris v. Unimarine [1979] 2 All E.R. 972; Chartered Bank v. Daklouche [1980] 1 All E.R. 205, and Prince Abdul Rahman v. Abu-Taha [1980] 3 All E.R. 409.

${ }^{13}$ Prince Abdul Rahman v. Abu-Taha, ibid.

${ }^{14}$ The Siskina [1977] 3 All E.R. 803, reversed by the H.L. ibid.

${ }^{15}$ Civil Jurisdiction and Judgments Act 1982, s.25.

${ }^{16}$ [1975] A.C. 396.
} 
a more nebulous practice of trying to find a "balance of convenience" between the parties, whatever that was. The general effect of that case was to make such injunctions a good deal easier to get - too easy, according to some, ${ }^{17}$ and it soon became clear that their trepidation was shared by Lord Denning. Like any sagacious judge choosing to postulate a general principle for the benefit of posterity, the members of the House of Lords in Cyanamid had wisely incorporated a let-out by qualifying their judgments with a "save in exceptional circumstances." And, as might have been foreseen, this was quickly seized upon. Public authorities were an early beneficiary. In Smith v. Inner London Education Authority, a group of Islington parents unsuccessfully tried to halt a school comprehensivisation plan in its tracks and sought an injunction to preserve the status quo ${ }^{18}$ When the case reached the Court of Appeal under Lord Denning, considerable sympathy was expressed, obiter, with the view that Cyanamid was inappropriate to deal with public bodies charged to act on behalf of the rest of us. ${ }^{19}$ And in the later De Falco v. Crawley Borough Council, one of the the earlier homelessness cases, the Cyanamid rule was said bluntly by his Lordship to have no application where the essence of the injunction claim was a challenge to such a body's actions on administrative law grounds. ${ }^{20}$ Of course, public authorities were not the only beneficiaries of this judicial scepticism: it soon became clear that there were other cases too where the propensities of the interlocutory injunction had to be tamed. Thus, as Lord Denning also quickly made clear, the strength of a party's case would not be disregarded where the interlocutory hearing was likely in practice to end the matter, as in the case of restrictive covenants on employees: whatever Cyanamid might have held, plaintiffs in such situations with weak cases should, and would, lose. Indeed Lord Denning himself would have gone further and resurrected the old practice where any important issue, such as the right of peaceful protest, was at stake. ${ }^{21}$ But here, as was often the case, he was in a minority and his views did not prevail. ${ }^{22}$

\footnotetext{
${ }^{17}$ For example, Prescott (1975) 91 L.Q.R. 168; Gore (1975) 38 M.L.R. 672. And see too Wallington's witty piece at [1976] C.L.J. 82-93.

18 [1978] 1 All E.R. 411.

19 Obiter, because the Court of Appeal was satisfied that the parents' case was a non-starter anyway: and even after Cyanamid, this has always been accepted as a ground for refusing the injunction.

${ }^{20}$ [1980] 1 All E.R. 913.

${ }^{21}$ See, for example, Fellowes v. Fisher [1976] 1 All E.R. 829.

${ }^{22}$ See Hubbard v. Pitt [1975] 3 All E.R. 1 (should demonstration against "yuppifying" estate agents be prevented by injunction?); [1996] C.L.J. 82 et seq.
} 


\section{REMEDIES: A NEGLECTED CONTRIBUTION}

\section{SPECIFIC REMEDIES AND INJUNCTIONS (2): SUBSTANTIVE RELIEF}

We now turn from interlocutory to final relief. Here, one might have thought the discretionary nature of specific remedies, with its concomitant opportunities for shielding the vulnerable and denying succour to the undeserving, would provide fertile ground for a reforming judge. Such a view would be particularly beguiling, indeed, since in practice pre- 1960 courts, while accepting that they always had a discretion in cases where they were asked for an injunction, had chosen to constrain it pretty closely. Thus in the nineteenth century the strong arm of the law had regularly been used to protect legal rights despite serious dislocation of communal life ${ }^{23}$ and at times remarkably murky motives on the part of plaintiffs. ${ }^{24}$

Oddly enough, however, any temptation to impugn such practices seems to have been largely spurned by Lord Denning. In cases such as Verrall v. Great Yarmouth Borough Council, granting specific relief to ensure a fringe political meeting went ahead despite the prospect of widespread distress and conceivably violence, the leading judgment which he gave was entirely consonant with the orthodoxy of the previous hundred years. ${ }^{25}$ Miller v. Jackson is the only judgment noticeably out of line with traditional thinking in this respect. ${ }^{26}$ There (it will be remembered) a householder in the Newcastle commuter-belt was refused an injunction against a cricket club which, in the course of providing a public amenity, persisted in driving cricket balls into his garden. This was at least partly on the basis that, whatever the position as to liability, communal recreation should not be sacrificed to private amenity ${ }^{27}$ - an approach which had indeed been roundly rejected in previous decisions such as Shelfer v. City of London Electric Co ${ }^{28}$ But even Miller was something of a special case. The plaintiff was, to say the least, a somewhat unsympathetic character, having knowingly bought a house next to an established cricket ground and then promptly complained of the inevitable effects of cricket being played on it. It is noticeable that

\footnotetext{
${ }^{23}$ Shelfer v. City of London Electric Co. [1895] $1 \mathrm{Ch} .287$.

${ }^{24}$ Cowper v. Laidler [1903] 2 Ch. 337 (enforcement of right to light despite pretty clear indications that claim being used for purposes of extortion).

${ }^{25}$ [1980] 1 All E.R. 839. See too Pride of Derby, etc., Angling Association v. British Celanese Ltd. [1953] Ch. 149 at 192, where Denning L.J. concurred in preventing a town council from polluting angling grounds with sewage despite the latter's plea that it had nowhere else to put it.

${ }^{26}$ [1977] Q.B. 966.

${ }^{27}$ lbid at p.981.

${ }^{28}$ Supra n.23.
} 
the leading judgment was aimed as much as anything at undermining the outdated rule that it is no defence that the plaintiff came to the nuisance ${ }^{29}$ as at rewriting the law of injunctions as a whole. ${ }^{30}$

Indeed, throughout the 1960s and 1970s the tendency was not so much to extend the grounds for refusing specific relief as to restrict them. ${ }^{31}$ Lord Denning's part in this process is exemplified by Hill v. C.A. Parsons \& Sons, a typical "closed-shop" case reflecting the bitter industrial climate of the period. ${ }^{32}$ Under trade union pressure, employers unwillingly sacked a number of long-standing non-unionists with entirely inadequate notice. The employees sought an injunction reinstating their employment; and, despite a long-standing acceptance that contracts of employment were not susceptible to specific performance or injunctions having equivalent effect, got it. However long-standing the practice against awarding the remedy, it was said, one had to look at the reason underlying it. Apart from the necessity to prevent employment becoming paid slavery (which explained the prohibition on specific performance against the employee) this was the undesirability of compelling employers to work with those whom they did not trust. Where this did not apply, there was no reason on principle to decline to give an injunction. In other cases, obviously the traditional rule should continue to apply. So much, indeed, was made clear by Lord Denning himself in a later trade union case, Chappell $\mathrm{v}$. Times Newspapers Ltd. in 1975, where the employee was not prepared to work normally and hence the trust and confidence that normally should exist between employee and employer was not there. ${ }^{33}$ The injunction was understandably refused.

What might be seen as Lord Denning's quietist policy in discretion cases was, however, amply counterbalanced elsewhere: namely, by a series of highly intriguing (though often unsuccessful) attempts to extend the courts' jurisdiction to grant injunctions in the first place. As regards common law claims within what has been called the "auxiliary" jurisdiction of equity, orthodoxy had always been straightforward and unbending: a defendant could not be restrained from doing something unless he would have been liable in damages - in tort or for breach of contract - had he done it. And indeed, in one sense this was hardly

\footnotetext{
${ }^{29}$ See Sturges v. Bridgman (1879) 11 Ch.D. 852: a case whose continued utility in these days of strict planning controls is, to say the least, doubtful.

${ }^{30}$ On the simple injunction point, Lord Denning's approach has indeed been discountenanced by a differently-constituted court: Kennaway v. Thompson [1981] Q.B. 88.

${ }^{31}$ See, for example, Price v. Strange [1978] Ch. 337 (searching examination of mutuality requirement, and consequent reduction in its ambit).

32 [1972] Ch. 305.

${ }^{33}$ [1975] 2 All E.R. 233.
} 
surprising. As soon as one characterises injunctions as a form of secondary equitable intervention available only where damages are inadequate, it seems to follow that if damages are not available at all, the grant of an injunction must a fortiori be precluded. Or does it? Standing back and looking at the matter from the point of view of principle, there is nothing theoretically absurd in a right enforceable by injunction but not sounding in damages; any oddity stems simply from the mindset of the common lawyer himself.

In three types of case, Lord Denning sought to exploit and develop precisely this idea, which (for want of a better term) can be termed the "autonomous" injunction. ${ }^{34}$ In the first he was ultimately unsuccessful: as regards the other two, it is perhaps fairest to say that the jury is still out.

One concerned the enjoining of crimes (leaving aside for these purposes the specialised locus standi of the Attorney-General, local authorities and other official bodies). The issue here is stark and clear. Since crimes vary from the heinous to the piffling, from the intentionally perverted to the entirely inadvertent, we cannot decently or justly mulct the criminal in damages for all their effects on the world at large. It is, indeed, for precisely this reason that an action for damages for breach of statutory duty is (quite rightly) not generously countenanced. On the other hand, crime of whatever kind ought to be repressed as well as penalised. It is not attractive to let a defendant say "I intend to commit a crime against your interests, and unless you can interest the prosecuting authorities there's nothing you or anyone else can do about it, so there." ${ }^{35}$ Acrow (Automation) v. Rex Chainbelt, Inc. was a case of this kidney in the Court of Appeal which provided a golden opportunity for some original law-making. ${ }^{36}$ The plaintiff, A, had got an injunction preventing $X$, which was an American company, from wrongfully terminating a distribution agreement with it. Under that distribution agreement, materials had been supplied to $A$ by $X$ and also by an associated company $Y$. Y, on X's instructions, withheld supplies from A, an act that was a contempt of court but not otherwise civilly actionable in damages at the suit of A. ${ }^{37}$ It was nevertheless held - Lord Denning presiding - that the court had jurisdiction to grant an injunction against

\footnotetext{
${ }^{34}$ I must confess to having first suggested that title: see "Injunctions without damages" (1987) 38 N.I.L.Q. 118.

${ }^{35}$ Compare the old case of Hayward v. East London Waterworks Co. (1884) 28 Ch.D. 138 (failure to provide fire hydrant: fact that no liability in damages no reason to refuse injunction).

${ }^{36}$ [1971] 3 All E.R. 1175.

${ }^{37}$ Chapman v. Honig [1963] 2 Q.B. 502 (an earlier decision of the Court of Appeal in which Lord Denning had dissented).
} 
$Y$ telling it to resume supplies, on the basis that $Y$ 's activity (or rather, non-activity) was unlawful, and that A stood to suffer special damage on account of it. True, it might have been argued that Acrow was a special kind of case, turning on the inherent jurisdiction to prevent court orders being flouted rather than on any more general principle applicable to the law of remedies. However, it had allowed the principle of the autonomous injunction to gain a toe-hold, and it was this toe-hold which Lord Denning characteristically caused to be consolidated a few years later. This later case was Ex parte Island Records Ltd., ${ }^{38}$ where an indignant recording company sought equitable relief against a number of bootleggers, gentlemen whose activities were (as the law then stood) criminal but not tortious, at least as against the plaintiffs. ${ }^{39}$ By a majority, the Court of Appeal followed his Lordship's lead in holding that, despite the lack of liability in damages, the bootlegging could be prevented at the suit of the plaintiffs. The basis was the same as in Acrow: where a defendant has committed a crime, and the plaintiff suffered particular damage, then he could obtain an injunction to prevent its continuance.

The reasoning in Ex parte Island Records had some instinctive attraction. It was, however, difficult to reconcile with an earlier House of Lords' decision, namely Lonrho Ltd. v. Shell Petroleum Co. Ltd. ${ }^{40}$ and was ultimately discountenanced by a differently-constituted Court of Appeal. ${ }^{41}$ As a result, it is now something of a historical footnote. The same cannot be said of the other two contexts in which Lord Denning dealt with similar issues.

The first of these was actually the earliest, and concerned the doctrine of restraint of trade (or an extension of it). In Nagle v. Feilden, the background was that the Jockey Club had always declined to license women trainers. ${ }^{42}$ It candidly admitted that it did so solely on grounds of their sex, but took the view - these being the halcyon days before the Sex Discrimination Act 1975 - that as a private body there was no reason why that should be anybody's business but its own. A female aspirant for a trainer's licence sued for, inter alia, an injunction, alleging that the Jockey Club's practice amounted to a restraint of trade which adversely affected her right to work. Now, there was no doubt that, even if this was a restraint of trade, no liability in damages could arise:

\footnotetext{
${ }^{38}$ [1978] Ch. 122.

${ }^{39}$ It is different today: Copyright, Designs and Patents Act 1988, ss. 185 et seq.

${ }^{40}$ [1982] A.C. 173

${ }^{41}$ In R.C.A. Corporation v. Pollard [1982] 3 All E.R. 771 (see especially per Oliver L.J. at pp.781-782).

${ }^{42}[1966] 2$ Q.B. 689.
} 


\section{REMEDIES: A NEGLECTED CONTRIBUTION}

agreements in restraint of trade might be unenforceable inter partes, but were not otherwise actionable by third persons. ${ }^{43}$ Nevertheless, the Court of Appeal refused to strike out the plaintiff's claim for an injunction: even if the defendant's course of conduct did not sound in damages (it was said) there was no necessary reason not to allow it to be enforced in other ways. Although somewhat enigmatic, and at times criticised, ${ }^{44}$ this decision has never been overruled, and has indeed been followed, both in England and elsewhere. ${ }^{45}$

The final example of innovativeness was the police case of Chief Constable of Kent $v . V .^{46} \mathrm{~A}$ fraudster had in his bank account some of his ill-gotten gains. The police understandably wanted to prevent him from dissipating them, and sought an injunction to that purpose. The difficulty was - as the defendant forcefully argued - that, while such disposal might be a crime and possibly a wrong against the victims, it was plainly not wrongful as against the police. Nevertheless, Lord Denning carried Donaldson L.J. with him, and the injunction issued by a majority. Apart from a technical point concerning the ambit of section 37 of the Supreme Court Act $1981,{ }^{47}$ the reasoning was beguilingly simple: the police had a right at common law to seize suspected stolen tangibles, and should be given a similar right, enforceable by injunction, to do the equivalent to intangibles. Although subsequent courts have expressed some puzzlement over the reasoning adopted, they have generally been content to accept the result (though not to extend it). ${ }^{48}$

\section{DAMAGES AND NON-SPECIFIC REMEDIES}

Lord Denning's influence on non-specific remedies has been less substantial, though still considerable. Some developments can clearly be laid at his door. The award of damages for breach of contract covering

\footnotetext{
${ }^{43}$ The House of Lords had, indeed, so held: see Mogul S.S. Co. v. McGregor, Gow \& Co. Ltd. [1892] A.C. 25.

${ }^{44}$ E.g. [1966] C.L.J. 165.

${ }^{45}$ England: Cooke v. Football Association, The Times, 24th March, 1972 (Foster J.). Australia: Buckley v. Tutty (1971) 125 C.L.R. 353 and Hall v. V.F.L. [1982] V.R. 64n. ${ }^{46}$ [1983] Q.B. 34.

${ }^{47}$ I.e., that because the section gave an ostensibly general power to issue injunctions, the court need not concern itself with whether the plaintiff had any kind of legal right at all. This point, which was expressed only by Lord Denning M.R., is clearly heretical: see per Lord Bridge, speaking for the House of Lords, in P. v. Liverpool Daily Post [1991] 2 A.C. 370 at 420.

${ }^{48}$ See in particular Chief Constable of Hants v. A. Ltd. [1985] Q.B. 132; and Chief Constable of Leics. v. M. [1988] 3 All E.R. 1015.
} 
non-financial losses was effectively instituted by his court in $1972,{ }^{49}$ and (it is sometimes forgotten) cemented in Heywood v. Wellers ${ }^{50}$ in 1976, where not only were such damages awarded against a solicitor, but an earlier decision of the same court to the opposite effect ${ }^{51}$ was airily bushed aside as ripe for reconsideration. And there are other cases where his decisions are cited without question as the leading authority. One example is the liability of a contract-breaker for pre-contract expenditure, which is normally traced back to a case in which he delivered the leading judgment. ${ }^{52}$ A more substantial pair of instances come in the otherwise recondite law of conversion, where the measure of recovery is (to say the least) curious. One is the ability of a conversion defendant to reduce the damages payable by him in so far as he has in good faith spent money in improving the subject-matter of the action ${ }^{53}$ (a proposition now, indeed, embodied in statute law ${ }^{54}$ ). The other is a wholesome exception to the rule setting damages arbitrarily at the full value of the property converted, applicable where the plaintiff is a finance company which has already been paid some or all of the instalments due on property subject to a hire-purchase agreement. ${ }^{55}$

These are the high-profile cases. A good deal more of his influence on remedial law has been less obvious, though clearly there under the surface. Nor is this very surprising. Decisions on technical points about the measure of recovery do not hit the legal headlines: when pronouncing on damages he has on the whole been less successful in carrying his colleagues with him: and, indeed, anyone who makes a virtue out of saying the (judicially) unsayable will ipso facto decrease the chances of his ideas prevailing. Indeed, Lord Denning, almost uniquely among the judges, has seen fit judicially to excoriate decisions of the House of Lords that were binding on him despite this being a pretty obviously quixotic exercise - see in particular his comments on House of Lords decisions on aspects of recovery for personal injury, and (most notoriously) his almost papal denunciation in Cassell \& Co.Ltd. v.

\footnotetext{
49 Jarvis v. Swans Tours Ltd. [1973] 1 All E.R. 171. According to Lord Denning M.R., there had been an unreported decision in the Court of Appeal 23 years earlier to the same effect. It is not clear, however, whether the point was seriously argued.

${ }^{50}$ [1976] 1 All E.R. 300.

${ }^{51}$ Groom v. Crocker [1939] 1 K.B. 194.

${ }^{52}$ Anglia T.V. v. Reed [1972] 1 Q.B. 60. There had been previous (contradictory) authority at first instance.

${ }^{53}$ Greenwood v. Bennett [1973] Q.B. 195.

${ }^{54}$ Torts (Interference with Goods) Act 1977, s.6.

${ }^{55}$ Wickham Holdings v. Brooke House Motors [1967] 1 All E.R. 117. A second authority establishing the same point, Belvoir Finance v. Stapleton [1970] 3 All E.R. 664, is also a decision of the Court of Appeal with his Lordship presiding.
} 


\section{REMEDIES: A NEGLECTED CONTRIBUTION}

Broome $^{56}$ of their Lordships' decision nearly a decade earlier to rein in punitive damages. $^{57}$

A good example of an unsuccessful attempt to change fundamentals arose out of Lord Denning's sage appreciation of the potential difficulties inherent in extensive personal injury liability and his attempts to deal with the problem. Often this has come up in the context of decisions on liability: ${ }^{58}$ but not always. In Lim Poh Choo v. Camden Health Authority, a well-paid victim of medical misfortune was relegated to lifelong incapacity. ${ }^{59}$ The defendants appealed a then colossal award of $£ 250,000$-odd, including tidy sums for both therapy necessitated and income foregone for the foreseeable future. They were not successful. Lord Denning M.R. however dissented, arguing that if the plaintiff received her costs of future nursing care there was no sensible reason to add to this a sum in respect of her loss of (now unspendable) income: such an award, he said, would benefit none but her heirs and the taxman. To the argument that this would leave a loss unrequited, he simply said it was time:

"to remove the misapprehension, so often repeated, that the plaintiff is entitled to be fully compensated for all the loss and detriment she has suffered. That is not the law. She is only entitled to what is, in the circumstances, a fair compensation, fair both to her and to the defendants."

However acceptable extra-judicially (the desirability of automatic full compensation is not beyond argument, especially to payers of tax and insurance premiums), this not surprisingly failed to find favour: indeed, the idea that loss might simply be allowed to go uncompensated was dismissed in a mere seven lines by Lord Scarman when the case went to the House of Lords. ${ }^{61}$ Nevertheless, the attack on the point of principle was resumed a couple of years later. Through medical negligence, an infant became paraplegic, with limited ability to understand his

\footnotetext{
56 [1971] 2 Q.B. 354 at 379 et seq. (the case went to the H.L. at [1972] A.C. 1027).

${ }^{57}$ l.e., Rookes v. Barnard [1964] A.C. 1129.

${ }^{58}$ In Whitehouse v. Jordan [1980] 1 All E.R. 650, at 657-658, for example, Lord Denning M.R. did not disguise his view that it should be more difficult to extract damages for medical negligence: and his restrictive judgment on what amounted to medical fault undoubtedly reflected this concern. The House of Lords disagreed with his view on the actual point in issue (whether a mere "error of judgment" could be negligence): see [1981] 1 All E.R. 267.

59 [1979] 1 All E.R. 332. The decision was varied in the House of Lords ([1979] 2 All E.R. 910 ) but on grounds not germane to the issue here.

${ }^{60}$ Ibid at p.340.

${ }^{61}$ See supra $\mathrm{n} .59$ at pp.920-921 per Lord Scarman.
} 
predicament. Besides the cost of future nursing care, the Court of Appeal awarded $£ 35,000$ for loss of amenity and a substantial sum for future loss of earnings. As in Lim, Lord Denning M.R. dissented, and as in Lim there was a good deal of sense in what he said: namely, that to award anything for lost earnings was to enter the realm of speculation and moreover to give money that could do no good to anyone, and further that there was something very odd in giving a practically insensible infant $£ 35,000$ for the loss of joys he would never know he could have had in the first place.

Lord Denning M.R.'s championship of a common-sense, impressionistic approach, free of obvious anomaly and with admixed in it a good deal more judicial discretion than is traditional in England, was not limited to personal injury cases. On the contrary, it runs through a good deal of his work on remedies. Take another example: the traditional distinction drawn between remoteness of damage as it affects breach of contract and tort, with the victim of the latter (it is said) more generously treated. ${ }^{62}$ This differentiation looks odd, especially since in an increasing number of cases a person can be liable both in contract and tort, the content of the duty being the same or similar whichever way it is expressed. This point is made more than once by his Lordship. ${ }^{63}$ Thus in Parsons v. Uttley Ingham, pig-farmers whose stock rather unexpectedly died from eating mouldy feed sued the container suppliers for breach of contract. ${ }^{64}$ The suppliers argued that this was precisely the sort of case where the contract-tort dichotomy made all the difference, and that even if recoverable in tort this loss was too remote for contract. The Court of Appeal was having none of it. Besides making this clear, Lord Denning went on to say that in his view that there should be no difference on principle between the two heads of liability. Although this opinion commanded general assent from the other two members of the court (Orr and Scarman L.JJ.), it must be said that it was better thought out: for, whereas the latter reached their conclusion on the somewhat vague ground that it was required by common-sense, Lord Denning argued rather more cogently not only that there was no difference between contract and tort, but that distinctions might have to be drawn between different kinds of claim (physical damage, loss of profit, etc) whatever

\footnotetext{
${ }^{62}$ For which traditionally The Heron $I I$ [1969] 1 A.C. 350 is cited.

${ }^{63}$ For example, in Cook v. S [1967] 1 All E.R. 299 at 303 ("At one time it was thought that damages in tort were different from damages in contract ... it is generally accepted, however, that in tort too the measure of damages is the reasonable foreseeability of the consequences"); and in Parsons v. Uttley Ingham, below.
}

${ }^{64}$ [1978] Q.B. 791. 
their legal basis. Needless to say this latter idea, however sensible, was too radical to carry the day.

Lastly, innovation. We have already mentioned one (minor) example where a wholesome neologism of Lord Denning's has found favour later in another, statutory, context: namely, the allowance given to an innocent improver against liability to damages for conversion. But there is, of course, another, better known, without which no account of Lord Denning's contribution to remedies would be complete. In the campaign leading to the enforcement of debts or damage liabilities in foreign currency, now commonplace, there is no doubt he was the prime mover. It is, indeed, a classic demonstration that, in law as elsewhere, the argument from authority is the weakest kind of argument, and is readily defeated by a combination of judicial activism and withering criticism from those in the know. ${ }^{65}$ The background was straightforward. In 1970 there was clear authority that courts and arbitrators could give judgment only in pounds sterling, this taking the form in the former case a House of Lords' decision dating back only eleven years. ${ }^{66}$ Nevertheless, by then no-one doubted that such a practice was uncommercial, rampantly outdated and, given sterling's dismal record on the exchanges, monstrously unfair to claimants. In Jugoslavenska Oceanska Plovidba v. Castle Investment $\mathrm{Co}$., the issue temptingly came up in the context of arbitrators. ${ }^{67}$ In a standard London charter arbitration, the claimants asked for an award in U.S. dollars to counteract the 1967 devaluation of the pound from $\$ 2.80$ to $\$ 2.40$. Kerr J. held they could not have it, but in effect begged the Court of Appeal to reverse him. The latter, under Lord Denning, duly obliged, blandly discountenancing previous dicta to the contrary in the same court. ${ }^{68}$ In Schorsch Meier GmbH v. Hennin the issue came up again. ${ }^{69}$ German creditors, owed an old debt in marks once equivalent to $£ 450$-odd but now worth a good deal more in sterling

\footnotetext{
${ }^{65}$ Similar examples in other areas include (topically) the demise of the "mistake of law" rule in Kleinwort Benson v. Lincoln C.C., The Times, 3rd November, 1998, and (earlier) the introduction of a limited landowners' duty towards trespassers in Herrington v. British Railways Board [1972] A.C. 877. This later was, of course, itself the culmination of yet another campaign by Lord Denning, as witness his earlier judgments in Miller v. South of Scotland Electricity Board 1958 S.C. (H.L.) 20, Videan v. British Transport Commission [1963] 2 Q.B. 666 and Kingzett v. British Railways Board (1968) 112 S.J. 625. ${ }^{66}$ Re United Railways of Havana \& Regla Warehouses Ltd. [1961] A.C. 1007.

${ }^{67}$ [1973] 3 All E.R. 498.

${ }^{68}$ See The Teh Hu [1969] 3 All E.R. 1200 at 1206 per Salmon L.J. Strictly speaking that case did not concern foreign currency awards, but whether an award in sterling could be increased to take account of sterling's depreciation against the claimant's currency of account. It was held (Lord Denning M.R. dissenting) that it could not.

${ }^{69}$ [1975] 1 All E.R. 152.
} 
terms, called on a bewildered London county court judge to give them judgment for it in marks. He understandably refused, and the creditors appealed. But this time it was more awkward than Oceanska Plovidba, since here the issue involved not an arbitration award but court enforcement of a debt, and the contrary authority was not a dictum in the Court of Appeal but a direct decision of the House of Lords. The Court of Appeal were in fact able to allow the appeal on the basis that the debt was an E.E.C. debt and that in such cases the Treaty of Rome had quietly abrogated the old "sterling-only" rule. But Lord Denning, with the agreement of Foster J., said for good measure that even without this he would have refused to follow the House of Lords' decision on the startling ground that the reasons underlying it no longer applied.

In the final and best-known case, Miliangos v. George Frank (Textiles) $L t d$, the E.E.C. let-out was unavailable, since the creditor was Swiss and uncompromisingly demanded payment in Swiss francs. ${ }^{70}$ Nevertheless, the Court of Appeal, once again under Lord Denning M.R., still held that the award could be made, on the basis that it was bound by its own previous decision in Schorsch Meier. Not surprisingly the matter then went to the Lords: and equally unsurprisingly that body tartly pointed out that its decisions ought to be loyally followed by the Court of Appeal. Nevertheless the pressure for change was irresistible, with the result that on the substantive point the final triumph went to Lord Denning: the 1961 decision was duly reconsidered, and it was of course decided that awards could after all be made in foreign currency.

\section{CONCLUSION}

Anyone trying to gauge the impact of a judge who spent a great deal of time in the Court of Appeal faces one obvious difficulty. The vast majority of the judgments on which one has to rely are not individual first-instance rulings where the source of inspiration is at least clear, but opinions delivered by one member of a three-person court, where as often as not the other two members also said what they thought rather than gamely limiting themselves to "I agree" or some such words.

On the other hand, there is no reason why this should be an insuperable awkwardness, any more than it was with (say) Lord Mansfield or Lord Atkin, both of whom again spent much of their judicial life in collegiate courts, but both of whom are now acknowledged as prime movers. As often as not, Lord Denning's judgment was the leading judgment; and leading judgments tend in their nature to be more substantial than others, and to give a lead to those that follow. And, of course, this is especially

${ }^{70}[1976]$ A.C. 443. 


\section{REMEDIES: A NEGLECTED CONTRIBUTION}

true where the person giving them has, virtute officii, considerable influence over which cases are allocated to whom. Moreover, where there is a series of them attacking one particular issue, their potential influence becomes more obvious still: it is hard to avoid the conclusion (for instance) that the events culminating in the acceptance of judgments expressed in foreign currency judgments in Miliangos v. George Frank were in large measure due to Lord Denning's continual efforts and pressure in that direction. Furthermore, his Lordship's opinions stand out in other ways too: they are normally memorably reasoned, and their ambit in many cases goes well beyond those of his colleagues on the bench. And, of course, there is one additional point. It must not be forgotten that in the Court of Appeal Lord Denning dissented more than most from his colleagues' views, and of course dissenting judgments create their own impacts anyway.

If one has to look for a theme pervading Lord Denning's judgments on remedies, it will (it is suggested) be found in the element of radicalism and almost academicism contained in them. They show a strong tendency to transcend the usual judicial question "should this or that principle be upheld?" and instead demonstrate an instinct now unfashionable in England to say "shouldn't we begin by starting from first principles and work from there?"71 The injunction cases are a matter in point: by-passing the traditional idea that injunctions secondary to $e x$ post facto remedies, they instead begin with the rather more important question of principle "when ought the plaintiff to be entitled to a preemptive remedy to protect his interests?" And similarly with the cases on personal injury damages: in cases such as Lim Poh Choo, the mysteries of supposedly universal compensation give way to more fundamental questions about why we have such damages in the first place, and a preparedness to question whether certain kinds of loss deserve compensating at all.

Such a propensity is, of course, deeply disconcerting to some, not least law students wanting the sort of straightforward answers that don't exist in the real world. It is also no doubt dangerous if overdone. A bench composed of law professors manqués, all chasing first principles and disagreeing with each other over what they should be, is a nightmare scenario of which the less said the better. But the law does need the occasional person in authority to stand back and stare at the edifice it has

\footnotetext{
${ }^{71}$ In possible contrast to other jurisdictions, e.g., Canada. A very neat example is Dickson J.'s judgment in Andrews v. Grand Toy Alberta Ltd. (1987) 83 D.L.R. (3d) 452 at 475 . The rationale for awarding damages for pain and suffering and other non-pecuniary loss in personal injury cases is carefully dissected with a view to rewriting the principles underlying such damages.
} 


\section{DENNING LAW JOURNAL}

created, to point out the obvious defects in the grand design, and to suggest that someone do something about them. In small quantities such conduct has done, and will continue to do, a great deal of good. We should all be grateful accordingly. 